\title{
Elastisitas Permintaan Beras Organik Di Kabupaten Hulu Sungai Utara
}

\section{(The Elasticity of Organic Rice Demand in Hulu Sungai Utara Regency)}

\author{
Muhammad Zaini ${ }^{1}$ \& Miranda Romaully Br. Sitanggang ${ }^{2)}$ \& Rum Van Royensyah ${ }^{3)}$ \\ Program Studi Agribisnis, Sekolah Tinggi Ilmu Pertanian Amuntai \\ ${ }^{1)}$ razni.140115@gmail.com \\ ${ }^{2)}$ miranda.rsd2203@gmail.com \\ ${ }^{3)}$ Vanroyensyah61@gmail.com
}

\begin{abstract}
ABSTRAK
Penelitian ini bertujuan untuk mengetahui faktor-faktor yang mempengaruhi permintaan beras organik dan elastisitasnya di Kabupaten Hulu Sungai Utara. Penelitian ini dilakukan di Kota Amuntai. Pengumpulan data dilakukan dari bulan Oktober 2018 sampai Januari 2019. Analisis yang digunakan adalah analisis regresi linier berganda dari hasil olahan perhitungan diperoleh persamaan regresi $Y=2,564+0,002\left(X_{1}\right)+1,025\left(X_{2}\right)-0,223\left(X_{3}\right)-1,511\left(X_{4}\right)+0,196\left(X_{5}\right)+0,003$ $\left(X_{6}\right)$. Hasil analisis untuk regresi diperoleh F-hitung 2,672 > F-tabel 2,53 dengan demikian hipotesis yang menyatakan bahwa variabel tingkat pendidikan, pendapatan, selera/kebiasaan, jumlah tanggungan, harga beras organik, dan harga barang lain (beras non organik) berpengaruh secara serempak terhadap permintaan beras organik. Sedangkan secara signifikan diperoleh hasil uji $t$ dimana nilai t-hitung 2,460 > t-tabel 1,713. Elastisitas permintaan untuk model statis berdasarkan elastisitas harga, harga beras organik bersifat elastis (7,32 > 1). Berdasarkan elastisitas silang, harga barang lain (beras organik) bersifat elastis $(5,27>1)$. Berdasarkan elastisitas pendapatan, pendapatan responden bersifat elastis $(702.615>1)$.
\end{abstract}

Kata Kunci: Permintaan, beras organik, elastisitas, pendapatan, harga.

\section{ABSTRACT}

This study is aimed to determine the factors that influence the demand for organic rice and its elasticity in Hulu Sungai Utara. This research was conducted in Amuntai City. Data collection was carried out from October 2018 to January 2019. The analysis us is multiple linear regression analysis from the results of calculations using the regression equation $Y=2.564+0.002\left(X_{1}\right)+1.025\left(X_{2}\right)-$ $0.223\left(X_{3}\right)-1,511\left(X_{4}\right)+0.196\left(X_{5}\right)+0.003\left(X_{6}\right)$. The results of the analysis for regression obtained F-count $2.672>$ F-table 2.53 thus the hypothesis which states that the variable of education level, income, tastes/habits, number of dependents, price of organic rice, and prices of other goods (nonorganic rice) have an effect simultaneously to the demand for organic rice. While significantly obtain the results of $t$-test where the value of $t$-calculation is $2.460>t$-table 1.713. The elasticity of demand for static models is based on price elasticity; the price of organic rice is elastic (7.32 > 1). Based on cross elasticity, the price of other goods (organic rice) is elastic (5.27 > 1). Based on income elasticity, respondents' income is elastic $(702,615>1)$.

Keywords: Demand, organic rice, elasticity, income, price.

\section{PENDAHULUAN}

Indonesia selain dikenal sebagai negara kepulauan dan negara maritim, juga dikenal sebagai negara agraris dengan luas sekitar 23\% dari luas keseluruhan. Hal ini karena posisi negara Indonesia berada di garis khatulistiwa, selain itu Indonesia juga dikenal sebagai negara yang memiliki gunung api aktif terbanyak di dunia yaitu sekitar 127 gunung api, sehingga dijuluki dengan "Ring Of Fire" oleh dunia. Hal tersebut merupakan nilai plus bagi Indonesia, karena tanah hasil eropsi gunung api umumnya sangat subur untuk aktifitas pertanian, khususnya tanaman pangan (Sutanto, 2012).

Tanaman pangan dalam pembangunan pertanian di Indonesia sangat mempunyai peranan penting, salah satunya yaitu untuk ketahanan pangan di Indonesia. Ketahanan pangan yaitu penyedia bahan makanan pokok untuk masyarakat Indonesia agar nantinya 
negara Indonesia tidak kekurangan bahan pangan. Tanaman pangan tersebut tidak dapat diganti secara sempurna oleh sub sektor pertanian lainnya (Harsono, 2017).

Tanaman pangan adalah suatu kebutuhan pokok manusia, agar dapat memenuhi kebutuhan hidupnya. Salah satu tanaman pangan yang dikonsumsi oleh masyarakat Indonesia yaitu padi atau beras. Akan tetapi, sekarang masyarakat melaksanakan kegiatan pertanian berusaha memanfaatkan sumber daya secara berlebihan sehingga merusak kondisi lingkungan dan biologi, misalnya seperti pemupukan kimiawi, penggunaan pestisida kimia, dan sebagainya. Sehingga nantinya akan berdampak pada kesehatan manusia (Sutanto, 2002). Sekarang banyak masyarakat Indonesia menginginkan pola hidup sehat, khususnya di bahan makanan. Pola hidup sehat saat ini sudah menjadi kebutuhan bagi sebagian besar masyarakat di Indonesia. Mereka sadar akan bahan makanan yang sehat yang bersumber dari pertanian organik. Salah satu bahan makanan yang mendasar adalah beras. Beras merupakan butiran buah padi yang berwarna putih yang telah dipisahkan dari kulitnya (sekam). Beras organik merupakan komoditas yang memiliki daya jual tinggi. Pola hidup sehat dengan konsumsi beras organik menjadi salah satu peluang petani agar mencukupi kebutuhan beras organik. Kebutuhan beras organik di Indonesia semakin hari semakin meningkat tajam. Beras organik merupakan beras yang berasal dari padi yang dibudidayakan secara organik atau tanpa pengaplikasian pupuk kimia dan pestisida kimia (Risty, 2009).

$$
\text { Semakin luasnya pertanian }
$$
organik, diharapkan bisa memberikan manfaat yang lebih luas dalam pemenuhan permintaan masyarakat akan pangan yang sehat dan berkelanjutan. Pertanian organik saat ini di Indonesia telah berkembang secara luas, baik dari sisi budidaya, sarana produksi, jenis produk, pemasaran, pengetahuan konsumen dan

organisasi/lembaga masyarakat yang menaruh minat pada pertanian organik
(Mayrowani, 2012). Tujuan penelitian yaitu, mengetahui faktok-faktor yang mempengaruhi permintaan beras organik dan elastisitasnya di Kabupaten Hulu Sungai Utara.

\section{METODE PENELITIAN}

Penelitian ini dilakukan di Kabupaten Hulu Sungai Utara Provinsi Kalimantan Selatan pada bulan Oktober 2018 sampai Januari 2019. Analisis yang digunakan yaitu Regresi Berganda, Uji Asumsi Klasik dan Analisis Elastisitas Permintaan. Regresi Berganda Untuk melihat faktor-faktor apa saja yang mempengaruhi permintaan beras organik diuji dengan menggunakan analisis regresi linier berganda. Parameternya diestimasi dengan metode OLS (Ordinary Least Square). Uji Asumsi Klasik Uji normalitas ini dapat dilakukan dengan menggunakan analisis grafik, Menurut Sarwoko (2005), cara yang mudah untuk mengukur multikolinieritas yaitu menghitung dengan varian inflation factor (VIF) yang merupakan cara mendeteksi multikolinieritas, uji heteroskedatisitas merupakan sebuah model dengan varian residual yang bersifat heteroskedatisitas. Analisis elastisitas permintaan dilakukan untuk mengetahui persentase kenaikan atau penurunan jumlah permintaan beras organik jika terjadi perubahan dari harga dan pendapatan.

\section{HASIL DAN PEMBAHASAN}

\section{Regresi Linier Berganda}

\section{Koefisien Determinasi $\left(\mathbf{R}^{2}\right)$}

Koefisien determinasi menunjukkan seberapa besar jumlah permintaan yang dapat diterangkan oleh semua faktor-faktor yang mempengaruhi permintaan beras organik tingkat pendidikan (X1), pendapatan (X2), selera/kebiasaan (X3), jumlah penduduk (X4), harga beras organik (X5), dan harga barang lain (beras non organik) (X6). Hasil penelitian koefisien determinasi kali ini dapat dilihat dari nilai yang telah 
Muhammad Zaini, Miranda \& Rum Van Royensyah, Elastisitas permintaan beras organik...

disesuaikan (adjusted $R$ square) dapat dilihat pada tabel berikut:

Tabel 1. Nilai Koefisien Determinasi

\begin{tabular}{llrrr}
\hline Model & $\mathrm{R}$ & $\mathrm{R}$ Square & Adjusted R Square & Std. Error of the Estimate \\
\hline 1 &, $551^{\mathrm{a}}$ &, 304 &, 122 & 1,906 \\
\hline
\end{tabular}

Sumber: Pengolahan data primer (2018).

Berdasarkan tabel diatas terlihat bahwa nilai Adjusted $\mathrm{R}$ adalah sebesar 0,122 hal ini menunjukkan bahwa $12,2 \%$ permintaan dapat dijelaskan oleh variabel pendidikan, pendapatan, jumlah penduduk, selera/kebiasaan, dan harga barang lain (beras non organik). Sedangkan 87,8\% dipengaruhi oleh variabel lain yang tidak termasuk dalam model regresi yang disebutkan diantaranya seperti umur dan jumlah penduduk. Umur salah satu faktor yang mempengaruhi permintaan beras organik, semakin umur manusia bertambah maka tingkat kesehatannya menurun dikarenakan tingkat konsumsi makanan yang kurang sehat. Oleh karena itu, manusia perlu memperbaiki pola makan yang sehat dengan mengkonsumsi beras organik. Sedangkan jumlah penduduk, yaitu ketika jumlah penduduk meningkat, maka akan meningkatkan jumlah permintaan beras organik, misalnya ketika penduduk berjumlah 200 orang dengan permintaan beras organik $100 \mathrm{~kg} / \mathrm{bulan}$. Ketika jumlah penduduk bejumlah 400 orang maka permintaan juga mengalami peningkatan. Untuk penelitian selanjutnya, peneliti dapat memasukkan kedalam variabel bebas, dan penelitian selanjutnya juga dapat menambah jumlah responden agar nilai $\mathrm{R}$ lebih dari 0,7 (kuat).

\section{Pengujian Serentak Seluruh Parameter Dugaan (Uji F)}

Uji $F$ digunakan untuk mengetahui semua variabel independen (Xi) dimana variabel (tingkat pendidikan $\left(\mathrm{X}_{1}\right)$, pendapatan $\left(\mathrm{X}_{2}\right)$, selera/kebiasaan $\left(\mathrm{X}_{3}\right)$, jumlah penduduk $\left(\mathrm{X}_{4}\right)$, harga beras organik $\left(\mathrm{X}_{5}\right)$, dan harga barang lain (beras non organik) $\left(\mathrm{X}_{6}\right)$, secara nyata berpengaruh terhadap variabe dependent (Y) yaitu jumlah permintaan beras organik di Kabupaten Hulu Sungai Utara. H0 ditolak jika F-hitung $\geq$ F-tabel, artinya semua variabel independen $(\mathrm{Xi})$ dalam persamaan ini secara serentak berpengaruh nyata terhadap permintaan beras organik. Sebaliknya H0 diterima jika F-hitung $\leq$ Ftabel, artinya semua variabel independen (Xi) dalam persamaan ini secara serentak tidak berpengaruh nyata terhadap permintaan beras organik (Suliyanto, 2011). Berikut ini adalah hasil uji statistik F yang dapat dilihat pada tabel dibawah ini:

Tabel 2. Hasil Uji Statistik F

\begin{tabular}{rlrrrrr}
\hline \multicolumn{1}{l}{ Model } & & Sum of Squares & df & Mean Square & F & Sig. \\
\hline \multirow{2}{*}{1} & Regression & 36,444 & 6 & 6,074 & 2,672 &, $004^{\text {b }}$ \\
& Residual & 83,556 & 23 & 3,633 & & \\
& Total & 120,000 & 29 & & & \\
\hline
\end{tabular}

Sumber: Pengolahan data primer (2018).

Berdasarkan tabel diatas, dapat dilihat bahwa uji $\mathrm{F}$ diperoleh nilai F-hitung sebesar 2,672 dengan tingkat signifikasi 0,004. Nilai F-tabel dengan tingkat kepercayaan $95 \%(\alpha=5 \%)$ dengan nilai df1 sebesar 6 dan df 2 sebesar 23 maka nilai Ftabel sebesar 2,53 dari hasil tersebut disimpulkan bahwa F-hitung $(2,672)$ lebih besar dari nilai F-tabel $(2,53)$ dan tingkat signifikansi 0,004 juga lebih kecil dari 0,05. Sehingga $\mathrm{H} 0$ ditolak dan $\mathrm{H} 1$ diterima artinya semua variabel independen secara simultan berpengaruh 
terhadap permintaan beras organik secara simultan dapat diterima.

\section{Pengujian Parameter Regresi Secara Tunggal (Uji t)}

Penggunaan uji t dilakukan dengan membandingkan nilai t-hitung dengan $\mathrm{t}$ tabel dengan pengujian dua arah dan tingkat kesalahan $\alpha=0,05$, maka nilai ttabel sebesar 1,713. Apabila t-hitung $>\mathrm{t}$ tabel maka dapat disimpulkan variabel tersebut mempunyai pengaruh yang signifikan, dan begitu juga sebaliknya. Berikut ini adalah hasil uji statistik t yang dapat dilihat pada tabel berikut ini:

Tabel 3. Hasil Uji Statistik t

\begin{tabular}{llrc}
\hline \multicolumn{1}{c}{ Model } & \multicolumn{1}{c}{ t } & \multicolumn{1}{c}{ sig. } \\
\hline \multirow{2}{*}{1 (Constant) } &, 266 &, 792 \\
& Harga Beras Organik &,- 801 &, 431 \\
& Jumlah Tanggungan & 2,460 &, 022 \\
& Selera &,- 149 &, 883 \\
& Pendapatan &,- 339 &, 738 \\
Pendidikan &, 510 &, 615 \\
& Harga Barang Lain &, 131 &, 897 \\
\hline
\end{tabular}

Sumber: Pengolahan data primer (2018).

Uji Asumsi Klasik

\section{Uji Normalitas}

Pada uji normalitas dapat dilihat dari Grafik Histogram dan Normal P-P
Plot Regression Standardized hasil pengolahana SPSS berikut ini:

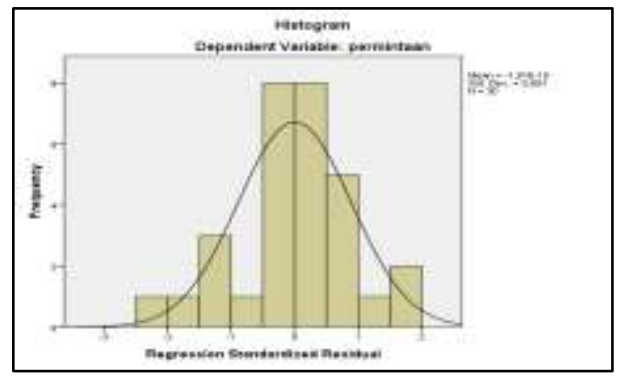

Gambar 3. Hasil Uji Normalitas (Output Histogram)

Berdasarkan Gambar 3, tampilan histogram terlihat bahwa kurva dependen variabel permintaan (Y) dan regression standardized residual membentuk gambar seperti lonceng. Oleh karena itu berdasarkan hasil dari uji normalitas secara histogram, analisis regresi layak digunakan atau tidak terjadi penyimpangan.

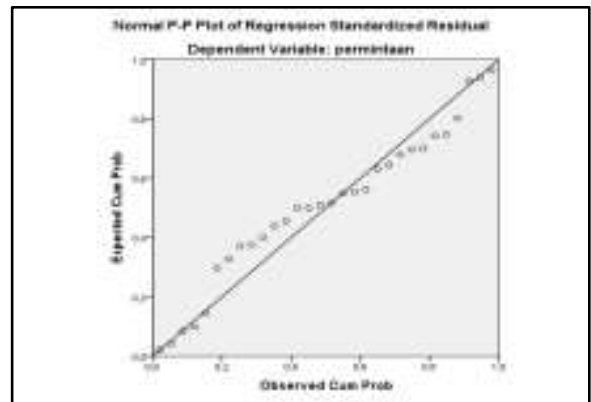

Gambar 4. Hasil Uji Normalitas (Normal P-P Plot of Regression Standardized Residual) 
Muhammad Zaini, Miranda \& Rum Van Royensyah, Elastisitas permintaan beras organik...

Berdasarkan tampilan pada Normal P-P Plot of Regression Standardized Residual terlihat bahwa titik-titik menyebar disekitar garis diagonal. Oleh karena itu, berdasarkan hasil dari uji normalitas analisis regresi layak digunakan meskipun terdapat sedikit plot yang menyimpang dari garis diagonal.

Menurut suliyanto (2011), hasil dari kedua uji normalitas tersebut dinyatakan bahwa hasil analisis regresi layak digunakan atau dikatakan berdistribusi normal, karena pada histogram membentuk gambar lonceng dan pada normal P-P Plot terlihat titik-titik menyebar disekitar garis diagonal. Sebaliknya jika tidak terpenuhinya normalitas umumya disebabkan karena distribusikan data yang dianalisis tidak normal atau adanya kesalahan dalam pengambilan sampel, bahkan kesalahan dalam menginput data.

\section{Uji Multikolinieritas}

Uji multikolinieritas dilakukan untuk mengetahui apakah variabel bebas tersebut tidak saling berkolerasi. Jika terjadi kolerasi diantara variabel bebas, maka terdapat gejala multikolinieritas. Uji mutikolinieritas ada atau tidaknya suatu gejala dapat dilihat dari nilai TOL (Tolerance) dan VIF (Varian Inflation Facktor) dari masing-masing variabel terikatnya. Jika VIF tidak lebih dari 10, maka model dinyatakan tidak terdapat gejala multikolinieritas (Suliyanto, 2011). Hasil perhitungan uji multikolinieritas dapat dilihat pada Tabel 4 berikut ini:

Tabel 4. Hasil Uji Multikolinieritas Dengan Menggunkan TOL dan VIF

\begin{tabular}{llcr}
\hline Model & \multicolumn{2}{c}{ Collinearity Statistics } \\
& (Constant) & Tolerance & VIF \\
\hline & Harga Beras Organik & & \\
& Jumlah Tanggungan &, 916 & 1,091 \\
1 & Selera &, 679 & 1,472 \\
& Pendapatan &, 870 & 1,149 \\
& Pendidikan &, 758 & 1,319 \\
& Harga Barang Lain &, 727 & 1,375 \\
&
\end{tabular}

Sumber: Pengolahan data primer (2018).

Berdasarkan hasil dari tabel diatas dapat dilihat bahwa nilai TOL 0,916 sedangkan nilai VIF pada variabel harga beras organik (X1) 1,091, nilai TOL 0,679 sedangkan nilai VIF pada variabel variabel jumlah tanggungan (X2) 1,472, nilai TOL 0,870 sedangkan nilai VIF pada variabel selera/kebiasaan (X3) 1,149, nilai TOL 0,758 sedangkan nilai VIF pada variabel pendapatan (X4) 1,319, nilai TOL 0,727 sedangkan nilai VIF pada variabel pendidikan (X5) 1,375, dan nilai TOL 0,956 sedangkan nilai VIF pada variabel variabel harga barang lain/beras non organik (X6) 1,046. Masing-masing variabel berjumlah kurang dari 10 maka dapat dinyatakan bahwa tidak ada gejala multikolinieritas (tidak terjadi penyimpangan asumsi multikolinieritas) atau tidak ada hubungan linier yang sempurna antara variabel independen dalam model.

\section{Uji Heteroskedastisitas}

Uji heteroskedastisitas dengan metode Glejser dilakukan dengan meregresikan semua variabel bebas terhadap nilai mutlak residualnya. Jika terdapat pengaruh variabel bebas yang signifikan terhadap nilai mutlak residualnya maka dalam model terdapat masalah heteroskedastisitas (Suliyanto, 2011). Berdasarkan hasil dari pengolahan data primer dibawah diketahui pada model regresi tidak terdapat gejala heteroskedastisitas. Hal ini karena semua Sig. Variabel independen terhadap absolut residual $(0,332,0,912,0,229,0,096,0,965$, 
Tabel 5. Hasil Uji Heteroskedastisitas dengan Metode Glejser

\begin{tabular}{|c|c|c|c|c|c|c|}
\hline \multirow{2}{*}{\multicolumn{2}{|c|}{ Model }} & \multicolumn{2}{|c|}{ Unstandardized Coefficients } & \multirow{2}{*}{$\begin{array}{l}\text { S. Coefficients } \\
\text { Beta }\end{array}$} & \multirow{2}{*}{$\mathrm{t}$} & \multirow{2}{*}{ Sig. } \\
\hline & & B & Std. Error & & & \\
\hline \multirow{7}{*}{1} & (Constant) & 5,529 & 5,582 & & ,991 & ,332 \\
\hline & $\begin{array}{l}\text { Harga Beras } \\
\text { Organik }\end{array}$ & $-1,178 \mathrm{E}-005$ & ,000 &,- 021 &,- 112 & ,912 \\
\hline & Jumlah Tanggungan & ,298 & 242 & 267 & 1,235 & 229 \\
\hline & Selera & 1,505 & 867 & 332 & 1,735 & 096 \\
\hline & Pendapatan & $1,147 \mathrm{E}-008$ & ,000 & ,009 & 044 & 965 \\
\hline & Pendidikan & ,274 & 223 & 257 & 1,228 & ,232 \\
\hline & Harga Barang Lain &,- 001 & 001 &,- 248 & $-1,362$ & 186 \\
\hline
\end{tabular}

Sumber: Pengolahan data primer (2018).

\section{Elastisitas Permintaan Beras Organik Di Kabupaten Hulu Sungai Utara}

Berdasarkan fungsi permintaan yang didapat dari perhitungan regresi linier berganda dapat dihitung nilai elastisitas permintaan beras organik. Elastisitas permintaan yang akan dihitung dalam penelitian ini adalah elastisitas harga, elastisitas silang, dan elastisitas pendapatan. Hasil perhitungan elastisitas permintaan beras organik dapat dilihat pada tabel dibawah ini:

Tabel 6. Hasil Perhitungan Elastisitas Permintaan Beras Organik

\begin{tabular}{clcccc}
\hline No & \multicolumn{1}{c}{ Variabel } & Koefisien Regresi & Rata-Rata & Elastisitas & Intervensi \\
\hline 1 & Permintaan & 2,564 & 5 & & \\
2 & Harga Beras Organik & 0,002 & 18.300 & 7,32 & Elastis \\
3 & Jumlah Tanggungan & 1,025 & 3,800 & 0,78 & Inelastis \\
4 & Selera & $-0,223$ & 0,933 & $-0,042$ & Inelastis \\
5 & Pendapatan & $-1,511$ & 2.325 .000 & 702.615 & Elastis \\
6 & Pendidikan & 0,196 & 3,000 & 0,12 & Inelastis \\
7 & Harga Barang Lain (Beras & 0,003 & 8.783 & 5,27 & Elastis \\
& Non Organik) & & & & \\
\hline
\end{tabular}

Sumber: Pengolahan data primer (2018).

Berdasarkan tabel diatas, dapat dilihat nilai elastisitas harga beras organik terhadap permintaan beras organik yaitu sebesar 7,32. Artinya dengan menurunkan harga sebesar 1 persen akan cendrung menaikan permintaan beras organik sebesar 7,32 persen. Elastisitas harga beras organik bersifat elastis $(7,32>1)$. Hubungan antara harga beras organik dengan jumlah permintaan beras organik sesuai dengan yang diungkapkan teori permintaan.

Hasil hitungan dari elastisitas silang dari harga beras non organik terhadap permintaan beras organik didapat nilai elastisitas sebesar 5,27. Artinya dengan menurunkan harga sebesar 1 persen akan cenderung menaikan permintaan beras organik sebesar 5,27 persen. Elastisitas harga beras organik bersifat elastis $(5,27>1)$.

Hasil dari perhitungan elastisitas pendapatan di dapatkan nilai elastisitas pendapatan sebesar 702.615. Artinya setiap kenaikan pendapatan konsumen sebesar $100 \%$ akan akan cendrung menaikan permintaan beras organik sebesar 702.615 persen. Elastisitas harga beras organik bersifat elastis $(702.615>1)$. Koefisien regresi yang didapat pada pendapatan responden adalah positif. 
Muhammad Zaini, Miranda \& Rum Van Royensyah, Elastisitas permintaan beras organik...

Permintaan beras organik akan meningkat jika pendapatan responden meningkat.

Berbeda dengan hal di atas Ulfa (2011), elastisitas harga tempe Di Desa Jombang Kecamatan Ciputat Kabupaten Tanggerang Selatan Provinsi Banten yaitu sebesar 0,957. Artinya dengan meningkatnya harga sebesar 1 persen akan menurunkan jumlah permintaan tempe sebesar 0,957 persen. Elastisitas harga tempe bersifat inelastis $(0,957<1)$. Elastisitas silang harga tahu terhadap permintaan tempe didapat nilai elastisitas sebesar 0,270. Elastisitas harga tahu bersifat inelastis $(0,270<1)$. Sedangkan elastisitas pendapatan didapatkan nilai elastisitas pendapatan keluarga sebesar 0,178. Elastisitas pendapatan bersifat inelastis $(0,178<1)$.

\section{KESIMPULAN}

Berdasarkan nilai F-hitung $(2,672)$ lebih besar dari F-tabel $(2,53)$ dan tingkat signifikansi 0,004 juga lebih kecil dari 0,05 ini berarti semua variabel tingkat pendidikan, pendapatan, selera/kebiasaan, jumlah tanggungan, harga beras organik, dan harga barang lain (beras non organik) secara nyata berpengaruh terhadap permintaan beras organik di Kabupaten Hulu Sungai Utara. Nilai Adjusted $R$ (koefisien determinasi) dari model reresi tersebut adalah sebesar 0,122 hal ini menunjukkan bahwa $12,2 \%$ permintaan dapat dijelaskan oleh variabel tingkat pendidikan, pendapatan, selera/kebiasaan, jumlah tanggungan, harga beras organik, dan harga barang lain (beras non organik). Sedangkan sisanya $87,8 \%$ dijelaskan oleh variabel lain atau faktor kesalahan (error). Elastisitas permintaan beras organik Berdasarkan nilai elastisitas harga beras organik terhadap permintaan beras organik yaitu sebesar 7,32. Artinya dengan menurunkan harga sebesar 1 persen akan cendrung menaikan permintaan beras organik sebesar 7,32 persen. Elastisitas harga beras organik bersifat elastis $(7,32>$ 1). Hubungan antara harga beras organik dengan jumlah permintaan beras organik sesuai dengan yang diungkapkan teori permintaan. Hasil hitungan dari elastisitas silang dari harga beras non organik terhadap permintaan beras organik didapat nilai elastisitas sebesar 5,27. Artinya dengan menurunkan harga sebesar 1 persen akan cendrung menaikan permintaan beras organik sebesar 5,27 persen. Elastisitas harga beras organik bersifat elastis $(5,27>1)$. Hasil dari perhitungan elastisitas pendapatan di dapatkan nilai elastisitas pendapatan sebesar 702.615. Artinya setiap kenaikan pendapatan konsumen sebesar $100 \%$ akan akan cendrung menaikan permintaan beras organik sebesar 702.615 persen. Elastisitas harga beras organik bersifat elastis $(702.615>1)$. Koefisien regresi yang didapat pada pendapatan responden adalah positif. Permintaan beras organik akan meningkat jika pendapatan responden meningkat.

\section{DAFTAR PUSTAKA}

Harsono. (2018, Oktober 10). Optimis Produksi Beras 2018, Kementan Pastikan Harga Beras Stabil. Retrieved from Kementerian Pertanian Republik Indonesia: https://www.pertanian.go.id /home/ ?show $=$ news \&act $=$ view $\&$ id $=2614$

Risty, C.T. and Iskandarini, G., (2013). Elastisitas Permintaan Beras Organik di Kota Medan. Journal of Agriculture and Agribusiness Socioeconomics, 2(2).

Suliyanto. (2011). Ekonometrika Terapan Teori \& Aplikasi Dengan SPSS. Yogyakarta: Andi.

Sarwoko. (2005). Dasar-Dasar Ekonome trika. Yogyakarta: Andi.

Susanto, D. (2015, Mei 25). Nusantara. Retrieved from Media Indonesia: https://mediaindonesia.com/.

Sutanto, R. (2002). Pertanian Organik. Yogyakarta: Penerbit Kanisius. 